Article

\title{
They Need More Than Technology-Equipped Schools: Teachers' Practice of Fostering Students' Digital Protective Skills
}

\author{
Priscila Berger* and Jens Wolling \\ Germany; E-Mails: priscila.berger@tu-ilmenau.de (P.B.), jens.wolling@tu-ilmenau.de (J.W.) \\ * Corresponding author \\ Submitted: 14 December 2018 | Accepted: 6 February 2019 | Published: 11 June 2019
}

Department Empirical Media Research and Political Communication, Technische Universität Ilmenau, 98693 IImenau,

\begin{abstract}
The intense use of digital media among children and adolescents raises concerns about online risks. In response, digital literacy frameworks for formal education usually include a set of protective skills. Considering that teachers have the responsibility to implement such frameworks, this study investigates factors associated with teachers' practices of fostering students' digital protective skills. Therefore, data from a survey conducted with 315 teachers in the state of Thuringia, Germany, was analyzed. The findings indicate positive associations between the importance teachers attribute to digital protective skills, the knowledge they have about guidelines for media education, their formal media training, and their media and technology use in class. Besides, the analysis revealed associations with school type, subject taught, and teacher age. Conversely, the factors of human and technological resources did not yield significant effects in the regression model. The final model explained $48 \%$ of the variance in the teachers' practices of fostering protective skills.
\end{abstract}

\section{Keywords}

digital literacy; digital skills; media education; online risk; protection of the private sphere; protective skills; teaching

\section{Issue}

This article is part of the issue "Critical Perspectives on Digital Literacies: Creating a Path Forward", edited by Hiller A. Spires (North Carolina State University, USA).

(C) 2019 by the authors; licensee Cogitatio (Lisbon, Portugal). This article is licensed under a Creative Commons Attribution 4.0 International License (CC BY).

\section{Introduction}

The concept of media education developed mainly due to the perceived necessity to protect children and adolescents from potentially harmful and offensive media content. The responsibility for children's consumption of traditional media, such as television, fell mainly on parents (Buckingham, 1996; Hogan, 2001). However, new media, which is consumed primarily through handheld devices, permits a high level of individualization. Therefore, youngsters can establish contacts and consume and produce media privately. In addition to challenging regulation, the use of digital media among young people raises a myriad of concerns about online risks, such as, pedophilia, invasion of privacy, bullying, commercial exploitation, and disclosure of personal infor- mation (Livingstone, Van Couvering, \& Thumim, 2004). Considering these new challenges, digital literacy frameworks for primary and secondary education have incorporated a set of protective skills, such as data protection and preservation of online identity (e.g., Ferrari, 2013; KMK, 2016).

In Germany, media education is compulsory, and its implementation is the responsibility of the federal states (KMK, 2012). The German state of Thuringia launched a media literacy program in 2009 called Kursplan Medienkunde to be implemented in the schools starting from the fifth grade. The program consists of a set of media-related competencies that students should develop in each school year. In an evaluation study of the Kursplan Medienkunde, six competency areas were identified, namely: (1) personal media use, (2) information 
use, (3) media influence in society, (4) practical technology use, (5) communication, and (6) protection of the private sphere (Wolling \& Berger, 2018).

Guidelines and curricula, such as the Kursplan Medienkunde, are usually developed at the policy level; however, the teacher has the most responsibility to implement the policies and promote media education (Brüggemann, 2013; Dias-Fonseca \& Potter, 2016; UNESCO, 2008). As media educators, teachers have been recognized as influential mediators of children's safe Internet use (Kalmus, Feilitzen, \& Siibak, 2012; Shin \& Lwin, 2017), which suggests that it is relevant to understand the practice of fostering protective skills among young people in the classroom. In this sense, we find two central relevant topics in the existent literature: (1) the roles that teachers assume in mediating youngsters' safe Internet use, and (2) teachers' pedagogical practices involving digital technologies. In relation to the latter, several studies have investigated factors associated with teachers' adoption of technology for instruction (e.g., Agyei, \& Voogt, 2011; Ertmer, 2005; Knezek \& Christensen, 2016; Petko, 2012); however, there is limited research on factors associated with teachers' fostering of digital literacy education, i.e., the pedagogical practice in which digital media is the subject-matter rather than a tool. The few studies that tackle this topic aim attention at the fostering of different areas of digital skills, such as computer and information literacy (Lorenz, Endberg, \& Bos, 2019; Siddiq, Scherer, \& Tondeur, 2016), evaluation of digital information (Hatlevik \& Hatlevik, 2018), and mediation of students' use of digital technology (Karaseva, Siibak, \& Pruulmann-Vengerfeldt, 2015). To the best of our knowledge, no study has investigated the factors associated with teaching digital protective skills specifically.

Considering this research gap, this study investigates factors associated with teachers' practice of fostering students' competency in the area of "protection of the private sphere." Therefore, we analyze data collected from 315 teachers who participated in a survey on teachers' opinions and practices regarding the Kursplan Medienkunde. Based on these findings, this study discusses how teachers can be better prepared to foster digital competency among their students.

\section{Teachers' Mediation in Safe Internet Use}

When it comes to fostering youngsters' protective media skills, research has explored the roles of socialization agents in regulating and mediating children and adolescents' Internet use, especially to avoid risky behavior. For instance, based on a literature review, Tejedor and Pulido (2012) examined the risks that children were exposed to on the Internet and discussed the involvement of teachers and parents in actions that could support children's online safety. Throughout the study, the responsibilities of teachers were emphasized more than those of the parents': "the figure and role of the teacher is crucial for minors to reach a critical, analytical and qualitative use of the Internet" (p. 67). Nevertheless, Livingstone Haddon, Görzig and Ólafsson (2011) showed that online safety advice is received primarily from parents, followed by teachers, and then from peers, based on a survey of children between nine and 16 years of age and their parents in 25 European countries. However, this rank changes according to demographics. For example, older teenagers and children with lower socioeconomic status reported receiving advice primarily from teachers. Using the same data, Kalmus, Feilitzen, and Siibak (2012) showed a positive relationship between teacher mediation and children's digital literacy and safety skills. However, teachers' mediating practice of helping children with something that bothered them on the Internet correlated negatively with skills, suggesting that less-skilled children might rely more on teachers for online safety guidance.

Jiménez-Iglesias, Garmendia-Larrañaga, and Casadodel-Río (2015) also found that parents and teachers are the main mediation agents for children's Internet use. In their qualitative analysis of focus groups and in-depth interviews with children aged nine to 16 years in Spain, the authors found that teachers are perceived as regulatory agents similar to parents and are expected to intervene in conflicts that happen at school. Similarly, Shin and Lwin (2017) showed that teachers were perceived to share a similar role to that of parents in certain types of mediations. In a survey of 746 adolescents between the ages of 12 and 18 years in Singapore, parents and teachers were considered influential agents in terms of advising on the adequacy of websites, what can and cannot be shared online, and how to proceed when someone bothers them on the Internet. However, teachers were perceived as the primary agent when it comes to suggesting ways to use the Internet safely.

These studies, conducted from the perspective of students, show that teachers play a meaningful role in guiding youngsters on how to use the Internet safely. However, to the best of our knowledge, there is a lack of research from the perspective of teachers, which would help to clarify the practice of fostering students' digital protective skills.

\section{Teaching Practices with Digital Technologies}

Among the teaching practices with digital technologies, the use of information and communication technologies (ICT) for instruction has received the most attention from researchers. While the use of ICT in class can be associated with a teacher's engagement in the fostering of media-related literacies (Hatlevik \& Hatlevik, 2018; Lorenz et al., 2019; Siddiq, Scherer, \& Tondeur, 2016), the two practices are not always synonyms. The adoption of ICT in class can facilitate learning about media, but it does not automatically correspond with a teacher's intention to foster media literacy. In most cases, the adoption of ICT in class aims to enhance the learning goals of other subjects (John, 2005), although students might develop media skills as a side effect. In the particular case 
of digital protective skills, it is unreasonable to assume that the mere use of ICT would lead to the development of such competency. The practice of fostering students' digital protective skills goes beyond the adoption of technology for teaching. Therefore, this study aims to answer the following research question:

RQ: How can teachers' practice of fostering students' digital protective skills be explained?

\subsection{Explaining the Practice of Fostering Digital Skills}

To develop a research model to answer our research question, we referenced studies that investigated teaching practices that used technology, especially the ones that revealed factors associated with promoting ICT skills among young people. As described below, we identified potential predictors and generated hypotheses from the results of these studies.

\subsubsection{Beliefs and Attitudes}

Teachers' beliefs about teaching and learning are one of the most influential factors affecting their decision to use ICT in the classroom (Ertmer, 2005) because "acceptance of the value and worth of technology is a critical component" of the adoption of technology (Knezek \& Christensen, 2016, p. 311). Research indicates that a favorable perception of the use of ICT in class is also an influential factor of teachers' efforts to promote digital skills among their students (Karaseva, Siibak, \& Pruulmann-Vengerfeldt, 2015; Lorenz et al. 2019; Siddiq et al., 2016). Our study does not measure the perceived relevance of ICT use in general, but rather focuses on teachers' perception of the importance of learning protective skills. Therefore, if a teacher believes in the importance of fostering protective skills among their students, we hypothesize:

H1. The level of importance teachers attribute to student learning of protective skills is positively associated with the practice of fostering students' protective skills.

\subsubsection{Knowledge of Media Education Guidelines}

Studies show that a teacher's self-efficacy in ICT is positively related to fostering students' digital skills (Hatlevik \& Hatlevik, 2018; Siddiq et al., 2016). ICT self-efficacy was not measured in the survey of teachers in Thuringia. However, we assume that understanding the state and national guidelines for media education, including the Kursplan Medienkunde, gives teachers a more solid idea of the topics that are involved in media literacy and what skills students should develop. Therefore, we hypothesize that these guidelines contribute to teachers feeling more prepared to foster students' digital skills in their practice:
H2. Teachers' knowledge of plans and guidelines for media education is positively associated with their practice of fostering students' protective skills.

\subsubsection{Training}

In order for media literacy initiatives to be successful in schools, it is necessary for teachers to prepare via pre-service and in-service training (UNESCO, 2008; Wilson, Grizzle, Tuazon, Akyempong, \& Cheung, 2011). It is assumed that receiving pre-service and in-service training for teaching with and about media has positive effects on the practice of fostering students' digital skills. However, until now, neither universities nor institutions in Germany that offer in-service training have included media-related topics sufficiently in their curricula (Tiede \& Grafe, 2016). Consequently, only a minority of teachers are prepared to teach media competency through their studies or by official institutions. Due to the lack of formal preparation, most teachers must acquire the needed knowledge and skills autonomously. It remains unclear whether teachers' autonomous learning of media-related issues has positive effects on the practice of media education. Contrarily, it seems plausible that instructors who rely predominantly or even completely on autonomous learning feel less confident and have a less solid idea of how to teach media-related subjects than those who receive formal preparation. Therefore, we assume:

H3. Teachers who must rely on autonomous learning foster students' protective skills less, while teachers with formal training on how to teach with and about media engage more in fostering digital protective skills among their students.

\subsubsection{School Resources}

It is important to consider that official and autonomous trainings are not the only ways that teachers can develop their digital capabilities. For instance, exchanging knowledge and ideas with colleagues can help teachers shape their practices with digital technologies (Ertmer, 2005). Lorenz et al. (2019) found that school support had a positive effect on teachers' fostering of students' computer and information skills by encouraging collaboration with colleagues and providing materials to develop ICT-based lessons. Even though Hatlevik and Hatlevik (2018) did not find a significant direct association between collegial collaboration and fostering students' skills in terms of evaluating digital information, collaboration between colleagues was significantly associated with teachers' ICT use in class, as well as their confidence in doing so.

We believe that other resources, aside from collaboration, could affect teachers' efforts to teach digital protective skills. For example, Lorenz, Endberg and Eickelmann (2016) found that having time to prepare lessons that integrate ICT was a positive predictor of 
technology integration in class. We believe that having the time to adapt lessons to accommodate the instruction about media could be an especially valuable resource for teachers in Thuringia, considering that the German guidelines for media education determine that the instruction about digital protective skills must happen within the realm of traditional school subjects (KMK, 2012). Moreover, research has indicated that the availability of sufficient ICT resources at school is a fundamental condition for teachers to involve digital technologies in their practices (Gil-Flores, Rodríguez-Santero, \& Torres-Gordillo, 2017; Lorenz et al., 2019; Petko, 2012). Although it is possible to promote students' protective skills without the presence of ICT in class, we argue that teachers can identify more opportunities to foster students' media literacy when they have the necessary ICT resources available at the school. Considering the human and technological resources mentioned above, we hypothesize that:

H4: Teachers' evaluation of school resources is positively related to their practice of fostering students' protective skills.

\subsubsection{ICT Use}

Besides the availability of resources, it is relevant to consider the extent to which teachers use them in their instruction. Studies have found that teachers' ICT use in class is positively associated with their practice of fostering digital skills (Hatlevik \& Hatlevik, 2018; Lorenz et al., 2019; Siddiq et al., 2016). Therefore, we expect that ICT use will be associated with the practice of promoting protective skills:

H5. The intensity of teachers' use of ICT in class is positively related to their practice of fostering students' protective skills.

\subsubsection{Subject, Age, and School Type}

Considering that the Kursplan Medienkunde should be integrated into traditional school subjects, it is reasonable to argue that the teaching of protective skills might fit better within the content of certain subjects. John (2005) elaborated on the integration of technology-related innovations in teachers' practice, indicating a complex negotiation process between their specific subject pedagogy and using ICT. While the integration of ICT generates changes and adaptations in the pedagogy, the original goals established in the subject shape, accommodate, and limit innovations during instruction. Regarding subject areas, studies have shown that science teachers tend to exhibit more positive pedagogical practices and attitudes toward technology than other teachers (Claro et al., 2018; Karaseva, Siibak, \& Pruulmann-Vengerfeldt, 2015), whereas Siddiq et al. (2016) found that humanities, languages, and arts teachers put greater emphasis on fostering students' computer and information literacy. In our analysis, we explore the possible relationships between various subjects and teachers' practices of fostering students' protective skills. We also include age in an exploratory character. Finally, we explore the relationship between the type of school and the extent to which teachers promote protective skills. Therefore, we state the following sub-research question:

SRQ: What are the associations between teachers' school types, subjects taught, ages, and practices in terms of fostering students' protective skills?

\section{Methods}

\subsection{Sample}

We tested our hypotheses using data collected from a teacher survey conducted in Thuringia, a federal state of Germany, in the summer of 2017. The sample was recruited through a random selection of 88 schools out 448 in which the Kursplan Medienkunde applies. We contacted the heads of the schools and asked them to distribute the questionnaire among the teachers in their schools, making it possible to reach more than 2700 teachers. The teachers had the option to fill out the questionnaire online via a link to the survey or by paper and pencil since copies of the questionnaire were sent to the schools along with a pre-stamped return envelope. Astonishingly, only $40 \%$ of the teachers answered online. After several reminder e-mails, 315 teachers participated in the survey (response rate of $12 \%$ ). The analysis of the data shows that the majority of the participating teachers (84\%) were directly engaged in teaching aspects of the Kursplan Medienkunde, while based on the information that we got from the head of the schools, an average of only $40 \%$ were involved with media education. Therefore, a self-selection process took place, and the sample consisted of teachers who were somehow involved or at least interested in the topic of media education. Nevertheless, the sample is quite similar to the population of teachers in Thuringia in terms of socio-demographic and structural characteristics. Table 1 shows that the percentage of female teachers is considerably higher in the sample and the general population. The distribution of age is quite similar, as well. Moreover, the proportion of teachers distributed throughout different school types in the sample is close to the teaching staff in the state. Therefore, the sample can be considered representative of teachers in Thuringia.

\subsection{Measures}

As mentioned in the introduction, this paper explains what associates with teachers' practice of the competency area "protection of the private sphere" in the Kursplan Medienkunde. To achieve this goal, we developed items based on the descriptions of the competency 
Table 1. Comparison of sample characteristics and distributions in the basic population (Statistisches Informationssystem Bildung, 2019).

\begin{tabular}{clrr}
\hline & Characteristics & Sample & $\begin{array}{c}\text { Basic Population } \\
\text { (Teachers in Thuringia) }\end{array}$ \\
\hline \multirow{2}{*}{ Age } & Up to 34 years & $16 \%$ & $11 \%$ \\
& 35 to 44 years & $10 \%$ & $8 \%$ \\
& 45 to 54 years & $37 \%$ & $39 \%$ \\
\hline \multirow{2}{*}{ Gender } & 55 years and older & $38 \%$ & $41 \%$ \\
& Female & $72 \%$ & $78 \%$ \\
School type & Male & $28 \%$ & $22 \%$ \\
& Gymnasium & $36 \%$ & $33 \%$ \\
& Standard school & $41 \%$ & $32 \%$ \\
\end{tabular}

areas provided by the Kursplan Medienkunde. Four indicators measured the dimension of protective skills. The teachers were asked to report how frequently $(1=$ never to 5 = often) they had instructed their students over the past year on the following topics: (1) how to handle cyber-bullying appropriately, (2) how to surf the Internet safely, (3) how to protect their data and private sphere effectively, and (4) how to detect when personal data has been collected and processed in network-media. These four items are strongly correlated (between $r=0.56$ and 0.80$)$ and comprise an exceptionally reliable scale $(\alpha=0.89)$.

The first explanatory factor is the perceived importance of the competency. The same four items as the outcome variable were applied to operationalize this factor, but with different introductory questions and answers. The teachers were asked to judge the importance of the four aspects on a scale from 1 (not important) to 5 (particularly important). The four items that measure importance were less correlated (between $r=0.27$ and 0.53) and the reliability of the scale was lower $(\alpha=0.70)$ compared to the variable that represents fostering protective skills.

The second explanatory factor is topic-related knowledge and the preparation of each teacher. Media education includes a broad field of skills and knowledge. On that account, measuring the respective knowledge of the teachers is a demanding task that cannot be thoroughly addressed by simple indicators. All measures are only rough approximations. Therefore, we decided to apply two approaches: The first refers to teachers' knowledge of media literacy education, as it relates to the syllabus. In Thuringia, this syllabus is comprised of four documents with various levels of concreteness. To measure this concept, we asked teachers how familiar they were with these documents on a scale from 1 (not at all) to 5 (very well). The four variables compose a reliable scale $(\alpha=0.77)$.

The second knowledge indicator relates to sources of topic-related skills. We asked teachers how they obtained the necessary skills to teach media literacy. We differentiated between formal preparation (pre-service studies and in-service training) and autonomous acquisition of skills. Four different competencies were considered: (1) critical deliberation of media use, (2) teaching students how to use media deliberately, (3) teaching students how to use media competently, and (4) dealing appropriately with cyber-bullying. Based on these four measures, we created a scale from -4 (teacher obtained all four skills autonomously) to +4 (teacher obtained all four skills through formal training).

The third influence factor refers to the resources available at the school. Once more, we considered two different approaches. First, we asked teachers how they would evaluate the quality and quantity of the resources available in their schools. A scale from 1 (not existent) to 6 (very good) was applied. Ten aspects were evaluated, six of which referred to human resources (e.g., support by colleagues and school principal, available time for further education and preparation) and four related to technological resources (e.g., quality and quantity of technical hardware, software, and Internet access). A factor analysis confirmed that the two aspects were discriminable dimensions of evaluation and both scales showed high reliability (human resources: $\alpha=0.88$, technological resources: $\alpha=0.92$ ).

The ICT use indicator operationalizes the intensity of digital media use during instruction. On a scale from 1 (never) to 5 (several times per week), the instructors reported how frequently they used four different types of computer programs (word processing, spreadsheets, presentations, and serious games), four different types of online resources (websites, search engines, online videos, and online communication), and four different types of hardware (computer-labs, interactive whiteboards, data projectors, and laptops) in the classroom. These twelve variables were averaged to build a composite scale $(\alpha=0.89)$.

Concerning school type, we differentiated between gymnasium, which is a secondary school in Germany that focuses on preparation for entering university (score of 1 ), and all other schools (score of 0 ). Regarding the 
subject areas, we asked the teachers to identify the subject areas where they have integrated media-related topics. It is unreasonable to address the "protection of the private sphere" in all subjects, and while this topic involves ethical, legal, and social concerns, it also requires technical understanding. Therefore, we identified the following 10 subjects in the areas of humanities, languages and informatics that might be relevant to this competency: (1) German, (2) geography, (3) history, (4) ethics, (5) economy and law, (6) economy and environment, (7) informatics, (8) religion, (9) social studies, and (10) humans, nature, and technology. Teachers who instruct at least one of these subjects were coded as 1 , and the others were coded as 0 .

\section{Findings}

The descriptive findings of our analysis already reveal some important insights (Table 2). The dependent variable measures how frequently teachers address the topic of "protection of the private sphere" in the classroom. The index indicates that the mean activity of teachers in this area was $3.3(S D=0.95)$ on a scale from 1 (never) to 5 (often). In contrast to the reported practice, the attributed relevance of competency is much higher. On a scale from 1 (not important) to 5 (particularly important), it achieved a value of 4.5 .

Concerning the indicators for knowledge and formal preparation, the results show that teachers in Thuringia rely mostly on the autodidactic acquisition of media education competency since formal education does not offer many opportunities in this area. A mean of -1.5 , on a scale from -4 (teacher obtained all four skills autonomously) to +4 (teacher obtained all four skills through formal training) indicates that autodidactic acquisition plays a more prominent role than formal training $(S D=1.8)$. Furthermore, the results show that on average, the teachers perceived their knowledge on the relevant documents to be better than regular $(M=3.2$, on a scale from 1 to 5 ).

The teachers also rated the perceived availability of human and technological resources as regular. Human resources were evaluated better $(\mathrm{M}=3.8)$ than technological resources $(M=3.6)$, on a scale from 1 (not existent) to 6 (very good). Moreover, the level of digital media use was an average of $2.8(S D=0.89)$, which is close to the middle of the scale (1-5).

Regarding the other control variables, we found that $36 \%$ of instructors in our sample work at a gymnasium and $67 \%$ teach subjects that have at least some potential to address aspects related to the "protection of the private sphere."

Bivariate correlations and hierarchical regression analyses were conducted to test the five hypotheses and to answer the sub-research question concerning the influence of school-type, subject, and age of the teachers. The correlation analysis shows significant relationships between all independent variables and the target variable (Table 3). Therefore, all variables were included in the regression analysis (Table 3 , Model 1 ). The results from the first regression model confirm the bivariate relationships with two exceptions. The positive effect of human and technological resources vanished when we controlled for the other factors. Therefore, these two factors were excluded, and the regression was calculated again (Table 3, Model 2). After eliminating these two variables, the final model contained only significant factors and successfully explained a considerable part of the variance (almost 50\%).

The first hypothesis ( $\mathrm{H} 1)$-the level of importance that teachers attribute to student learning of protective skills is positively associated with their practice of fostering students' protective skills-was strongly supported by the data. The teachers perceived this skill to be important, and it had a significant and positive effect on their practice. Likewise, the second hypothesis $(\mathrm{H} 2)$ that assumed a positive relationship between the teachers' knowledge of plans and guidelines for media education was also confirmed by the data. However, the impact of knowledge was considerably lower compared with attitudes. Also the second hypothesis related to knowledge (H3), which predicts a positive relationship between teachers' formal training in media, was also proven by the analysis; while formal training strength-

Table 2. Descriptive results.

\begin{tabular}{|c|c|c|c|c|}
\hline & Scale & $M / \%$ & SD & $\mathbf{n}$ \\
\hline \multicolumn{5}{|l|}{ Dependent variable } \\
\hline $\begin{array}{l}\text { Protection of the private sphere (Index: four items) } \\
\text { Independent variables }\end{array}$ & 1 to 5 & 3.29 & 0.95 & 314 \\
\hline Importance given to competency (Index: four items) & 1 to 5 & 4.51 & 0.45 & 313 \\
\hline Knowledge of plans (Index: four items) & 1 to 5 & 3.24 & 0.88 & 313 \\
\hline Formal vs. autonomous training (Index: four items) & -4 to +4 & -1.47 & 1.80 & 315 \\
\hline Technological resources (Index: six items) & 1 to 6 & 3.63 & 1.17 & 307 \\
\hline Human resources (Index: six items) & 1 to 6 & 3.82 & 1.10 & 310 \\
\hline ICT use in class (Index: 12 items) & 1 to 5 & 2.81 & 0.89 & 313 \\
\hline Type of school (gymnasium yes/no) & $1 / 0$ & $36 \%$ & & 307 \\
\hline Relevant subjects (yes/no) & $1 / 0$ & $67 \%$ & & 315 \\
\hline
\end{tabular}


Table 3. Results of bivariate correlations and hierarchical regression analyses.

\begin{tabular}{lccc}
\hline Predictors & Bivariate Correlation & Model 1 & Model 2 \\
\hline Competency area: protection of the private sphere & $r$ & beta & beta \\
\hline Importance given to competency & $0.38^{* * *}$ & $0.30^{* * *}$ & $0.30^{* * *}$ \\
Knowledge of plans & $0.47^{* * *}$ & $0.16^{* *}$ & $0.16^{* *}$ \\
Formal vs. autonomous training & $0.12^{*}$ & $0.11^{*}$ & $0.11^{*}$ \\
Technological resources & $0.13^{*}$ & $(-0.02)$ & - \\
Human resources & $0.23^{* * *}$ & $(0.03)$ & - \\
ICT use in class & $0.46^{* * *}$ & $0.35^{* * *}$ & $0.35^{* * *}$ \\
Kind of school: gymnasium & $-0.23^{* * *}$ & $-0.17^{* * *}$ & $-0.17^{* * *}$ \\
Relevant subjects & $0.25^{* * *}$ & $0.09^{\#}$ & $0.10^{*}$ \\
Age & $0.24^{* * *}$ & $0.14^{*}$ & $0.15^{* *}$ \\
$\mathrm{R}^{2}$ & & 0.49 & 0.48 \\
F & & $27.57^{* * *}$ & $35.73^{* * *}$ \\
Durbin-Watson & & 1.94 & 272 \\
$\mathrm{~N}$ & & & 1.94 \\
\hline
\end{tabular}

Notes: ${ }^{* *} \mathrm{p}<0.001 ;{ }^{* *} \mathrm{p}<0.01$ * $^{*} \mathrm{p}<0.05$; $^{\#} \mathrm{p}<0.10$.

ened teachers' engagement in fostering protective skills, we found that relying on autonomous learning had the opposite effect.

The fourth hypothesis $(\mathrm{H} 4)$ assumed that the better the teachers evaluated the school resources, the more they would foster students' protective skills. However, the data did not support this assumption: neither human nor technological resources seem to be associated with teachers' engagement when the model includes other predictors. However, the indicator that represents the use of resources had the strongest effect (beta $=0.35$ ) on the outcome variable. Therefore, the last hypothesis ( $\mathrm{H} 5$ ) "the intensity of teachers' use of ICT in class is positively related to their practice of fostering students' protective skills" was confirmed. In terms of our sub-research question, we found that instructors teaching in gymnasium placed less emphasis on fostering students' protective skills, and the subjects identified as relevant for fostering protective skills yielded a small positive and significant effect. Finally, the findings suggest that older teachers invest more in fostering students' digital protective skills.

\section{Discussion}

This study aimed to determine what factors were associated with teachers' practice of fostering students' digital protective skills. The findings of our analysis supported most of our hypotheses. The exception was the positive relationship that we expected to exist between resources and fostering protective skills, which was rejected. Considering only bivariate correlations, it is possible to see a small but significant positive association, especially with human resources. However, when controlling for other factors, resources lost their significance. Similarly, in Hatlevik and Hatlevik's (2018) work, collegial collaboration was found to have no direct effect on fostering students' digital information skills. However, their analysis showed that collegial collaboration was signifi- cantly associated with self-efficacy and ICT use, which had a significant effect on teaching digital skills. Therefore, we do not discredit the importance of school support for teachers' practice of fostering protective skills among their students. We believe these findings suggest a more complex relationship exists between the following three elements: (1) external conditions for teachers' practice, such as resources, (2) teachers' agency (i.e., attitudes, ICT adoption, and confidence), and (3) teachers' practice of fostering digital skills. Moreover, the area of digital literacy emphasized in the teaching might mediate the effect of teachers' perception of school resources on their practice of teaching media-related skills. For instance, Lorenz et al. (2019) identified a direct relationship between school support and teachers' practice of fostering skills in the area of computer and information literacy. Meanwhile, Hatlevik and Hatlevik (2018), who analyzed the area of evaluating digital information, and our study that focused on the area of digital protective skills found no direct associations with school resources.

Regarding technological resources specifically, teachers' actual use of available resources yielded the strongest effect, even though the perceived availability of resources did not deliver a significant result in our analysis. When teachers employ the available technologies in their activities, the probability that they will also engage in teaching protective skills rises significantly. Obviously, teachers cannot use what they do not have available. Nonetheless, it is possible that resources provided at school go unused (Knezek \& Christensen, 2016). In this sense, while the availability of resources is a fundamental condition for use, teachers' engagement with technology has a stronger effect on teaching about digital protective skills.

According to previous research, teachers' beliefs about the relevance of ICT for teaching and learning determine whether teachers will use the resources provided at their schools (Ertmer, 2005; Lorenz et al., 2016; 
Petko, 2012; Siddiq et al., 2016). Our findings show that teachers' attitudes are a relevant factor for teaching digital protective skills, as well. When teachers consider "protection of the private sphere" to be important, they make a stronger effort to foster it. The descriptive findings showed that the perceived relevance of protective skills is already high among the sample. However, some teachers still do not attribute high relevance to the subject. Therefore, it is imperative to make teachers conscious of the importance of digital protective skills, as well as of their roles as mediators of youngsters' safe Internet use (Kalmus, Feilitzen, \& Siibak, 2012; Shin \& Lwin, 2017).

Concerning the role of knowledge, we found that it is meaningful to inform teachers about the goals of media education because those who know about the guidelines tend to integrate the issue into their classroom activities. In terms of teacher training, we must acknowledge that it is problematic to expect teachers to obtain the necessary knowledge and skills through autodidactic means. The findings show that only formal preparation has a positive effect on teaching practice. Guidelines and official training (pre-service and in-service) might help teachers understand the priorities of media education, what content should be taught, and how media-related topics could be integrated into traditional school subjects. In-service and pre-service training would also show teachers how to incorporate ICT into the classroom meaningfully and encourage its use, while simultaneously promoting the importance of teaching protective skills.

In addition to the stated hypotheses, this study explored relationships between the type of schools where teachers work, the subjects they teach, their ages, and the practice of fostering students' protective skills. The results show a lower incidence of practice among gymnasium teachers. The reason for this result could be that gymnasium focuses on preparing students for university; therefore, teachers tend to have a more focused curriculum with little room for topics that do not fall under the criteria for admission. Moreover, high social selectivity has been demonstrated in the German school system (Müller \& Ehmke, 2013). Students who live in high socioeconomic conditions are five times more likely to be recommended to attend gymnasium than children from lower-income families (Wernstedt \& John-Ohnesorg, 2008). Moreover, previous studies show that children with lower socioeconomic status tend to rely more on teachers for advice on safe Internet use (Livingstone et al., 2011); therefore, teachers who work in non-gymnasium schools might assume higher responsibility for fostering students' protective skills.

The findings also showed that protective skills were facilitated through specific school subjects. Our analysis showed that subjects in the areas of languages, humanities, and informatics were more favorable for integrating media protective skills. This result is partly in line with the findings of Siddiq, Scherer and Tondeur (2016), but does not coincide with the results of Claro et al. (2018) who found that science teachers had greater ability to in- struct students on digital tasks. However, it is crucial to highlight that Claro et al. analyzed the ability of teachers to convey digital tasks rather than their actual teaching practices. When it comes to practice, specific subjects and characteristics of the school curriculum facilitate the practice and others hinder it, even if the teacher has the ability to teach digital skills.

The difference between ability and practice also appears in the aspect of age. Our findings indicate that older teachers tend to foster students' protective skills more, while in the study by Claro et al. (2018), younger teachers showed more skills in teaching digital literacy. However, Claro et al. also reveal that teachers with more experience exhibit higher ability. In this sense, the positive association that we found between age and fostering protective skills might be related to the time they have spent in service rather than their age. Moreover, it is valid to consider the specific characteristics of teachers in Thuringia, which is the population of our study. First, the average age of teachers in this German federal state for the 2017-2018 school year was 50.3 years (Statistisches Informationssystem Bildung, 2019). Second, most of these teachers were born and raised in the former German Democratic Republic. Therefore, it is plausible to assume that the topic of "protection of the private sphere" could be especially sensitive for older teachers who lived under constant observation by the state. This sensitivity could affect the importance they give to protective skills in the digital context.

Our findings show that the practice of fostering students' digital protective skills is connected mainly to teachers' agency, i.e., their attitudes toward the importance of the topic and their use of technology. Therefore, to stimulate teachers in their roles as mediators for safe online practices among young people, investments should promote and facilitate these factors. Germany is currently considering a digital pact ("DigitalPakt Schule") that would increase investments in technological equipment and infrastructure in schools. Our findings suggest that the mere existence of technology is not enough for teachers to promote digital protective skills. However, guidelines for media education and teacher training about media have the potential to shape and stimulate this practice. We believe that training could successfully raise teachers' awareness about the relevance of the topic and their roles as media educators. Therefore, it is imperative that the investments planned within the German digital pact enhance teacher training and provide guidelines, goals, and regulations for media education. Furthermore, instead of expecting or demanding that all teachers promote digital protective skills, it is reasonable to direct efforts to teachers in subjects and types of schools that are more relevant to this practice. Thus, the training initiative should prioritize specific subjects, such as humanities and informatics, as well as schools that have a higher concentration of students with lower socioeconomic status. 


\subsection{Limitations and Future Research}

While our study included predictors that have not been analyzed in previous literature, namely knowledge of guidelines and training, our analysis might not have analyzed sufficiently the complexity of factors that surround teaching practices that foster digital skills. A path analysis and structural equation modeling might be more suitable for identifying the direct and indirect relationships between factors.

Previous studies identified the role that teachers' selfefficacy plays in fostering digital skills. While we offered a unique perspective of skills, including knowledge of plans and guidelines of media education, as well as inservice and pre-service training, we had no available measures of how prepared teachers feel to convey digital protective skills. This is a shortcoming of our study, especially considering that $60 \%$ of our sample chose to answer the survey with pen and paper instead of the online version, which might suggest a lack of confidence with digital tools. Future studies should include measures of self-efficacy, knowledge of guidelines, and level of training to investigate the relationships between these factors, as well as how their interactions affect the practice of fostering digital skills.

Moreover, our study took place in a specific context, which was the federal state of Thuringia, Germany. Since the federal states are responsible for media education in Germany, it is important to conduct studies that compare the practice of digital literacy in different states. Moreover, the study has a self-selection bias. Although the survey was aimed at all teachers, $84 \%$ of respondents reported fostering at least one of the six areas of the Kursplan Medienkunde. Therefore, we need to consider that our results come predominantly from a biased sample of teachers who are involved in the topic of media literacy. Consequently, our results might have shown a more negative picture regarding resources, attitudes, and all other components, if more teachers unrelated to media education had participated.

Most results of this study are in line with previous studies that investigated other areas of digital skill, confirming factors that play a role in the practice of fostering digital competency. On the other hand, it also identified associations between factors that have not been investigated before. Therefore, this study contributes to the development of a more comprehensive model that explains teachers' practice of media literacy. Future studies should test the model presented in this paper with other competency areas to identify factors that apply to the practice of fostering students' digital literacy in general, and factors that are specific to particular competency areas.

\section{Acknowledgments}

The project was financed and supported by the Ministry of Education, Youth and Sports of Thuringia (Thüringer
Ministerium für Bildung, Jugend und Sport). We acknowledge support for the Article Processing Charge by the German Research Foundation (DFG) and the Open Access Publication Fund of the Technische Universität Ilmenau.

\section{Conflict of Interests}

The authors declare no conflict of interests.

\section{References}

Agyei, D. D., \& Voogt, J. M. (2011). Exploring the potential of the will, skill, tool model in Ghana: Predicting prospective and practicing teachers' use of technology. Serious Games, 56(1), 91-100. https://doi.org/ 10.1016/j.compedu.2010.08.017

Brüggemann, M. (2013). Digitale Medien im Schulalltag: eine qualitativ rekonstruktive Studie zum Medienhandeln und berufsbezogenen Orientierungen von Lehrkräften [Digital media in the school reality: A qualitative reconstructive study of media management and teachers' professional orientation]. München: Kopaed.

Buckingham, D. (1996). Moving images: Understanding children's emotional responses to television. Manchester: Manchester United Press.

Claro, M., Salinas, A., Cabello-Hutt, T., San Martín, E., Preiss, D. D., Valenzuela, S., \& Jara, I. (2018). Teaching in a digital environment (TIDE): Defining and measuring teachers' capacity to develop students' digital information and communication skills. Computers \& Education, 121, 162-174. https://doi.org/10.1016/ j.compedu.2018.03.001

Dias-Fonseca, T., \& Potter, J. (2016). Media education as a strategy for online civic participation in Portuguese schools. Comunicar, 24(49), 9-17. http://dx.doi.org/ 10.3916/C49-2016-01

Ertmer, P. A. (2005). Teacher pedagogical beliefs: The final frontier in our quest for technology integration? Educational Technology Research and Development, 53(4), 25-39. https://doi.org/10.1007/BF02504683

Ferrari, A. (2013). DIGCOMP: A framework for developing and understanding digital competence in Europe (JRC Scientific and Policy Reports No. EUR 26035). Luxembourg: Publications Office of the European Union.

Gil-Flores, J., Rodríguez-Santero, J., \& Torres-Gordillo, J.-J. (2017). Factors that explain the use of ICT in secondary-education classrooms: The role of teacher characteristics and school infrastructure. Computers in Human Behavior, 68, 441-449. https://doi.org/ 10.1016/j.chb.2016.11.057

Hatlevik, I. K. R., \& Hatlevik, O. E. (2018). Students' evaluation of digital information: The role teachers play and factors that influence variability in teacher behavior. Computers in Human Behavior, 83, 56-63. https://doi.org/10.1016/j.chb.2018.01.022

Hogan, M. J. (2001). Parents and other adults: Models 
and monitors of healthy media habits. In D. Singer \& J. Singer (Eds.), Handbook of children and the media (pp. 663-680). London: Sage Publications.

Jiménez-Iglesias, E., Garmendia-Larrañaga, M., \& Casadodel-Río, M. A. (2015). Percepción de los y las menores de la mediación parental respecto a los riesgos en Internet [Kids' perceptions of parental mediation concerning internet risks]. Revista Latina de Comunicación Social, 70, 49-68.

John, P. (2005). The sacred and the profane: Subject sub-culture, pedagogical practice and teachers' perceptions of the classroom uses of ICT. Educational Review, 57(4), 471-490. https://doi.org/10.1080/ 00131910500279577

Kalmus, V., von Feilitzen, C., \& Siibak, A. (2012). Effectiveness of teachers' and peers' mediation in supporting opportunities and reducing risks online. In S. Livingstone \& L. Haddon (Eds.), Children, risk, and safety on the Internet: Research and policy challenges in comparative perspective (pp. 245-256). London: Policy Press.

Karaseva, A., Siibak, A., \& Pruulmann-Vengerfeldt, P. (2015). Relationships between teachers' pedagogical beliefs, subject cultures, and mediation practices of students' use of digital technology. Cyberpsychology: Journal of Psychosocial Research on Cyberspace, 9(1). http://dx.doi.org/10.5817/CP2015-1-6

KMK. (2012). Medienbildung in der Schule-Beschluss der Kultusministerkonferenz vom 8. März 2012 [Media education at school-Resolution of the Kultusministerkonferenz from 8. March 2012]. Retrieved from http://www.kmk.org/fileadmin/ Dateien/veroeffentlichungen_beschluesse/2012/ 2012_03_08_Medienbildung.pdf

KMK. (2016). Bildung in der digitalen Welt: Strategie der Kultusministerkonferenz [Education in the digital world: Strategy of the Kultusministerkonferenz]. Berlin: Sekretariat der Kultusministerkonferenz.

Knezek, G., \& Christensen, R. (2016). Extending the will, skill, tool model of technology integration: Adding pedagogy as a new model construct. Journal of Computing in Higher Education, 28(3), 307-325. https:// doi.org/10.1007/s12528-016-9120-2

Livingstone, S., Haddon, L., Görzig, A., \& Ólafsson, K. (2011). Risks and safety on the Internet: The perspective of European children. Full Findings. London: EU Kids Online.

Livingstone, S., Van Couvering, E., \& Thumim, N. (2004). Adult media literacy: A review of the research literature. London: Ofcom.

Lorenz, R., Endberg, M., \& Bos, W. (2019). Predictors of fostering students' computer and information literacy-Analysis based on a representative sample of secondary school teachers in Germany. Education and Information Technologies, 24(1), 911-928. https://doi.org/10.1007/s10639-018-9809-0

Lorenz, R., Endberg, M., \& Eickelmann, B. (2016). Unterrichtliche Nutzung digitaler Medien von Lehrkräften der Sekundarstufe I in Deutschland und im Bundesländervergleich [Teachers' classroom use of digital media in secondary school in Germany and the federal states in comparison]. In W. Bos, R. Lorenz, M. Endberg, B. Eickelmann, R. Kammerl, \& S. Welling (Eds.), Schule digital-Der Länderindikator 2016: Kompetenzen von Lehrpersonen der Sekundarstufe I im Umgang mit digitalen Medien im Bundes/ändervergleich [Digital school-The Länderindikator 2016: Teachers' competencies in use of digital media in secondary school in the federal states] (pp. 80-109). Münster: Waxmann.

Müller, K., \& Ehmke, T. (2013). Soziale Herkunft als Bedingung der Kompetenzentwicklung [Social background as condition for the development of competencies]. In M. Prenzel, C. Sälzer, E. Klieme, \& O. Köller (Eds.), PISA 2012. Fortschritte und Herausforderungen in Deutschland [PISA 2012. Progress and challenges in Germany] (pp. 245-275). Münster: Waxmann.

Petko, D. (2012). Teachers' pedagogical beliefs and their use of digital media in classrooms: Sharpening the focus of the 'will, skill, tool' model and integrating teachers' constructivist orientations. Computers \& Education, 58(4), 1351-1359. https://doi.org/ 10.1016/j.compedu.2011.12.013

Shin, W., \& Lwin, M. O. (2017). How does "talking about the Internet with others" affect teenagers' experience of online risks? The role of active mediation by parents, peers, and school teachers. New Media \& Society, 19(7), 1109-1126. https://doi.org/10.1177/ 1461444815626612

Siddiq, F., Scherer, R., \& Tondeur, J. (2016). Teachers' emphasis on developing students' digital information and communication skills (TEDDICS): A new construct in 21st century education. Computers \& Education, 92/93, 1-14. https://doi.org/10.1016/ j.compedu.2015.10.006

Statistisches Informationssystem Bildung. (2019). Statistik im Schulbereich: Thüringen im Schuljahr 2017/18. [Statistics of the school sector: Thuringia in the school year 2017/18] Retrieved from http://www.schulstatistik-thueringen.de/pdf/ Statistikplakat_A3g.pdf

Tejedor, S., \& Pulido, C. (2012). Retos y riesgos del uso de Internet por parte de los menores. ¿Cómo empoderarlos? [Challenges and risks of kids' internet use. How to empower them?] Comunicar, 20(39), 65-72. https://doi.org/10.3916/C39-2012-02-06

Tiede, J., \& Grafe, S. (2016). Media pedagogy in German and U.S. teacher education. Comunicar, 24(49), 19-28. http://dx.doi.org/10.3916/C49-2016-02

UNESCO. (2008). ICT competency standards for teachers. Paris: UNESCO.

Wernstedt, R., \& John-Ohnesorg, M. (2008). Soziale Herkunft entscheidet über Bildungserfolg. Konsequenzen aus IGLU 2006 und PISA III. [Social background decides about success in education. Consequences from the IGLU 2006 and the PISA III] Berlin: 
Friedrich-Ebert-Stiftung. Retrieved from http:// library.fes.de/pdf-files/stabsabteilung/05314.pdf

Wilson, C., Grizzle, A., Tuazon, R., Akyempong, F., \& Cheung, C. K. (2011). Media and information literacy curriculum for teachers. Paris: UNESCO. Retrieved from http://unesdoc.unesco.org/images/0019/ 001929/192971e.pdf
Wolling, J., \& Berger, P. (2018). Die Vermittlung von Medienkompetenz in allgemeinbildenden Schulen: Zentrale Ergebnisse eines Evaluationsprojekts [Fostering media literacy in general education schools: Central results of an evaluation project]. IImenau: IImenau Universitätsverlag.

\section{About the Authors}

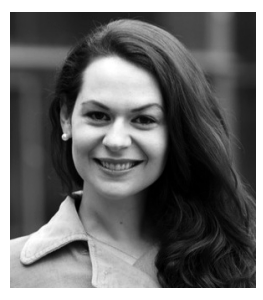

Priscila Berger is a Research Assistant and PhD Candidate in the Department of Empirical Media Research and Political Communications at the TU IImenau (Germany). Her academic background consists of a bachelor's degree in Communication Studies (UFSM, Brazil), a vocational teaching degree (UFSM, Brazil) and a master's degree in Media and Communication Science (TU Ilmenau). Her main research interests are digital media in educators' practices and media literacy education.

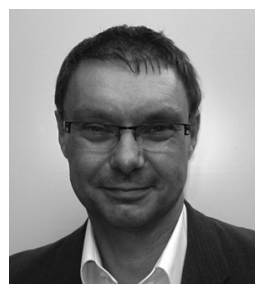

Jens Wolling is a Professor of communication research and political communication at the TU IImenau (Germany). He has studied communication science and history at the Freie Universität Berlin and has worked as a researcher at the TU Dresden and as a Professor at the Ludwig-Maximilians-Universität (Munich). He has conducted research on a large variety of issues related to political communication and media. 